\title{
SUSTAINABLE DEVELOPMENT AND MANAGEMENT OF SURFACE AND GROUNDWATER IN COOUM SUB BASIN OF CHENNAI BASIN USING REMOTE SENSING AND GIS
}

\author{
K. Nagamani ${ }^{1}$, P. Mohana ${ }^{1}$ and K. Santhanam ${ }^{2}$ \\ ${ }^{1}$ Scientist C, Center for Remote Sensing and Geoinformatics, \\ Sathyabama Institute of Science and Technology, Chennai, India \\ ${ }^{2}$ Scientist D, Center for Water Resources, Sathyabama \\ Institute of Science and Technology, Chennai, India \\ *E-mail: nagamaniloganathan@ gmail.com
}

\begin{abstract}
Water is the most valuable renewable natural resource for preserving all forms of living on earth. It is an economically productive resource and it is the main source of economic structures. In recent decades the surface water resources are fully utilized in the 17 most important river basins of Tamil Nadu and this is a main problem in the State. Sub-basins located near East Coast, face seawater intrusion problem. Cooum sub-basin of Chennai basin located in Thiruvallur and Chennai districts suffer due to pollution, saltwater intrusion problems. Hence, a study was undertaken in the Cooum subbasin. Collateral data on groundwater level, quality, soil, geology, drainage, rainfall and as maps were generated using GIS software in digital format. By interpreting high-resolution remote sensing satellite data, thematic layers as land use, geomorphology and waste lands were prepared. Existing anicuts, reservoirs were also marked with details. Water potential assessment was analyzed and sectoral demands were estimated. Degraded areas were distinctly marked. Favorable zones for further development were chosen and the map was prepared. Remedial measures were also suggested. The potential, draft, balance of water were derived scientifically by utilizing modern remote sensing and GIS techniques.

Keywords: sustainable development, surface and groundwater, remote sensing, GIS, Cooum subbasin, Chennai Basin
\end{abstract}

(C) RASĀYAN. All rights reserved

\section{INTRODUCTION}

The human essential and economic development are important for sustainable development of conservative environment with the resourceful use of natural resources, that make sure substitution between preferred production and consumption levels.

Due to rapid growth (i.e.,) Most of the wetlands in the study area are converted to Information Technology (IT) industries and residential apartments ${ }^{8}$ and its suburbs and also due to population growth the river is highly deteriorated in every aspect. Water Resources are increasingly threatened by:

- Poor maintenance of irrigation tanks and their supply channels due to its loss of water conservation.

- Over utilization and Inefficient use of surface water for agriculture,

- Over utilization of groundwater for agriculture and rural water supply and

- Excessive use of chemical fertilizers and pesticides for agriculture

The groundwater cultivation yields are high compared to those in the canal irrigated $\operatorname{areas}^{6}$. In India, the groundwater-irrigated area accounts for about 50 percent of the total irrigated area and up to 80 percent of the country's total agricultural production may, in one form or another, be dependent on groundwater ${ }^{1}$. Still, the availability of groundwater for irrigation only cannot make sure augmented yields as recognized around the world. The availability of groundwater is essential as a part of a complementary and commonly strengthens the set of other technologies. Surface water resources are fully utilized and due to 
overuse of groundwater in the 17 most important river basins of Tamil Nadu is a very big problem in the State. Remote Sensing (RS) and Geographical Information Systems (GIS) now play a major role in inventorying and observing of natural resources.

The main problems encountered in Cooum sub-basin are:

- Sub-basins located near East Coast, face seawater intrusion problem.

- Cooum sub-basin of Chennai suffer due to pollution, saltwater intrusion problems

This paper deals with the possibility of releasing minimum water flow in the Cooum river for keeping the river clean in Chennai City from the savings of water in upper reaches in the Agriculture sector water utilization by adopting modern technology and better water management technologies.

\section{Study Area}

In earlier days the Cooum is also called as Triplicane river. Coovum name is derived from Tamil literature. The Cooum River originates from Cooum tank in Thiruvallur district of Tamil Nadu and flows towards the east for a distance of $65 \mathrm{~km}$. The river confluences with the Bay of Bengal at Chennai City. The length of the river in Chennai City limits is $16 \mathrm{~km}$. The Cooum Sub-basin is in Chennai Basin. The area of the subbasin is 682 sq.km. It is situated between latitude $12^{\circ} 54^{\prime} 30^{\prime \prime}$ and $13^{\circ} 9^{\prime}$ and longitude $79^{\circ}$ $36^{\prime} 30^{\prime \prime}$ and $80^{\circ} 1^{\prime}$ '. Kosasthaliyar subbasin is in the north, Palar basin and Adayar sub basin lies in the south and Bay of Bengal in the eastern side. The location map is shown in Fig.-1.

The Korattur Anicut constructed in 1879 across Cooum in the middle reach of Cooum diverts water to Chembarampakkam tank through New Bangaru channel and surplus from Chembarampakkam tank flows into Adayar river.

\section{Objectives}

The main objectives of the study on sustainable development and management of surface and groundwater in Cooum sub-basin of Chennai basin are

- To prepare different themes such as land use, Geomorphology and wastelands using remote sensing and GIS.

- To generate the collateral data on groundwater level, quality, soil, geology, drainage, and rainfall using GIS software in digital format.

- To access the water potential and sectoral demands in Cooum sub basin.

- To prepare favorable zones for the study area.

\section{EXPERIMENTAL}

Our country mostly depends on two main resources such as land and water resources. Due to overpopulation, the resources are in exhaustion. So there is more essential to deal with these resources. The integration of remote sensing and GIS is now more effective for the analysis to obtain sustainable development. The satellite datasets which is used for the current study are IRS LISS-II 2005 \& IRS LISSIII 2013 of 1:50,000 scale were classified visually for preparation of thematic layers such as land use/land cover, hydrogeomorphology and soil.

With the help of characteristics of the satellite image like location size, shape, shadow, tone/colour, texture, pattern, height/depth and site/situation/association were carried out interpretation of photo-image and layouts were prepared for the above-specified themes All these layouts were checked with ground truth verification using field surveyed through Global Positioning System (GPS) and finalized the maps. To categorize the name of villages in the study area, latitude and longitudes with diverse reference points had plotted on the satellite images which is based on the 1:50,000 scale of Survey of India (SOI) toposheet. The overlay analyses (all thematic layers) were processed for land irrigation and for natural resource evaluation purpose.

Recommendations are given with the base study and availability of resources and conditions which are observed in the field, an alternative livelihood sustainability as cultivating like forestry, horticulture and 
plantation and also brief given for more efficient water resource methods and practices for harvesting surface water.

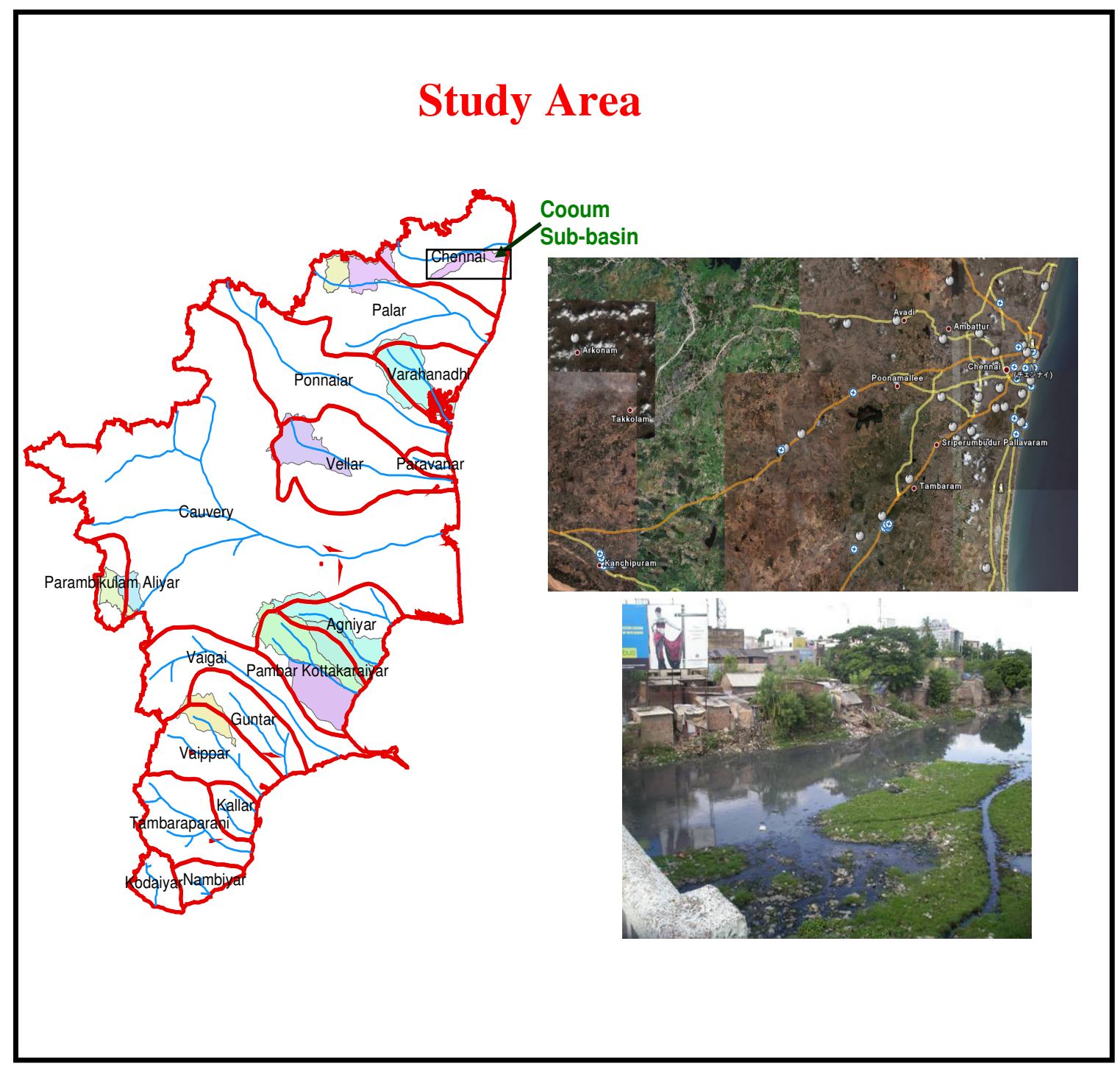

Fig.-1: Location Map for the study

\section{Land Use}

\section{RESULTS AND DISCUSSION}

The base for any type of research in the land is mainly focused on mapping land use and the land cover information is essential for local to the regional level of study. In this research paper, this base study such as land use /land cover plays a vital role in sustainable development/management of the local community. In the Cooum sub-basin Chennai is Located. There is pressure for land for all the sectors such as housing, industries, agriculture etc. Urbanization and expansion of Industries encroach on the agriculture land. The statistical data of land use and land cover is given in Table-1 and the spatial distribution of the same is shown in Fig.-3.

\section{Agricultural Area}

Agriculture is the major use of the land, water and biological resources in the World. This is the main occupation of this area. In the current study the observation with the help of the image interpretation 
reveals that the area under study is predominantly an agricultural region. In study area, maximum areas come under cultivation and it occupies 183 sq. km (27\%) of the total study area.

\section{Built-up land (Rural, Town/Cities)}

It is classified as an urban area and is categorized by urban morphology as settlements; road \& rail networks and rural areas are classified as villages of human habitation. The classification of urban area in satellite imagery was based on tone, color and location with the association. The settlement is demarcated in the satellite image which is seen as grayish \& light bluish color. The total area of urban classification are occupied in the study area is $123 \mathrm{sq} \mathrm{km} \mathrm{(18 \% )} \mathrm{and} \mathrm{the} \mathrm{rural} \mathrm{area} \mathrm{occupied} \mathrm{the} \mathrm{total} \mathrm{area} \mathrm{of} 12 \mathrm{sq} \mathrm{km}$ $(2 \%)$.

\begin{tabular}{|c|}
\hline SOCIO ECONOMIC DATA \\
- Population \\
- Landholdings \\
- Occupations
\end{tabular}

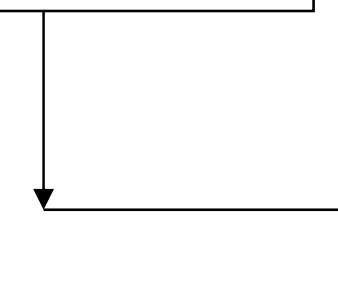

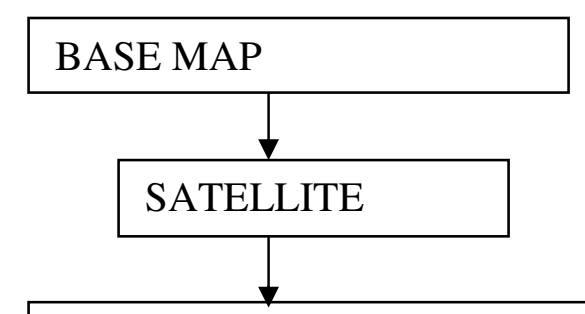

THEMATIC MAPS PREPARED

- Land use Map

- Geomorphology Map

- Wasteland Map
COLLATERAL DATA

- Soil

- Geology

- Drainage

- Groundwater level

- water quality

- Rainfall

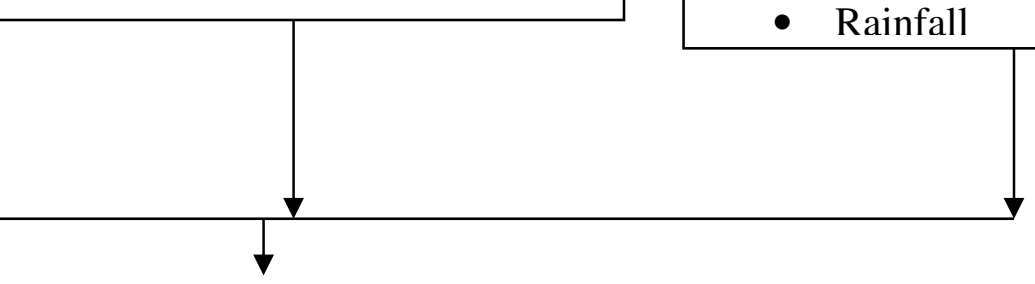

Favorable Zonal Map
for Surface and

Fig.-2: Methodology for sustainable development and management of surface and ground water in Cooum Sub Basin of Chennai Basin

\section{Water Bodies}

It includes natural water bodies and manmade water features like lakes, ponds, tanks and reservoirs which flowing as rivers, streams and canals. These features in satellite data are represented tone as light blue to dark blue with a smooth texture. Due to the absorption of IR radiation, the water bodies are seen dark blue in the satellite imagery. The total geographic distribution of water bodies like tanks /reservoirs and river/streams are $32 \mathrm{sq} \mathrm{km}$ and $26 \mathrm{sq} \mathrm{km}$ respectively and the same is given in Table- 1 .

\section{Other Categories}

This category is included other uncultivated land, excluding the current fallows. In our study, the other category is classified as aquaculture pond and it occupies the very negligible area.

\section{Soil Type}

Mapping the soil information constitute a visualization of soil types and their specific areas of distribution. The following orders of soils are found in the sub basin as per remote sensing data is shown in Table-2 and Fig.-4. 


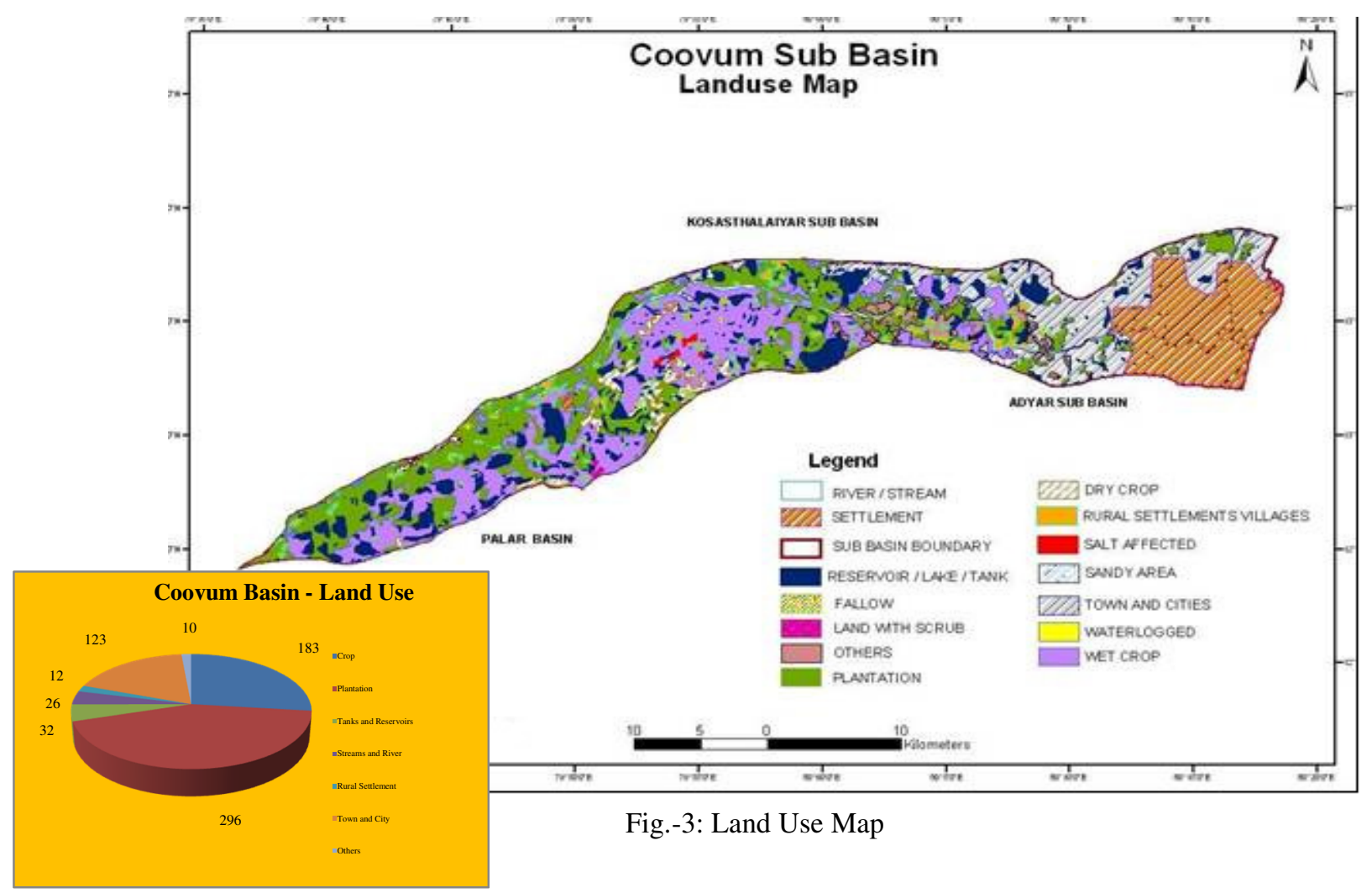

Table-1: Land use Pattern in Cooum Basin, Chennai

\begin{tabular}{c|c|c}
\hline Land use & Area $-\mathrm{km}^{2}$ & Percentage (\%) \\
\hline Crop & 183 & 27 \\
\hline Plantation & 296 & 43 \\
\hline Tanks and Reservoirs & 32 & 5 \\
\hline Streams and River & 26 & 4 \\
\hline Rural Settlement & 12 & 2 \\
\hline Town and City & 123 & 18 \\
\hline Others & 10 & 1 \\
\hline Total & 682 & 100 \\
\hline
\end{tabular}

Alfisols are arable soils with water content adequate for at least three consecutive months of the growing season. In the study areas which are occupied are $154 \mathrm{sq} \mathrm{km}(23 \%)$.

Entisols are described as they don't show any development in the profile other than an A horizon. In this study entisols are occupied of about $118 \mathrm{sq} \mathrm{km}(17 \%)$ of the total area.

Incepsols are the type which is weakly developed, but they are more developed than entisols. This type can be mostly seen in steep slopes or wet areas. These types of soils are occupied in the study area of about $331 \mathrm{sq} \mathrm{km} \mathrm{(49 \% ).} \mathrm{Vertisols} \mathrm{are} \mathrm{the} \mathrm{soils} \mathrm{which} \mathrm{are} \mathrm{clayey} \mathrm{with} \mathrm{the} \mathrm{less} \mathrm{organic} \mathrm{matter,} \mathrm{can} \mathrm{be}$ mostly seen in wet and dry seasons. Wetness substance differs in the study area and occupies a negligible area.

\section{Geology}

The sub-basin is underlined by the formation of Archaean to recent age. Crystalline rocks of Archaean age comprising granite gneises, charnockite and associated basic and ultra basic igneous and metamorphic rocks cover the west. Sedimentary formations of Gondwana, tertiary, quaternary and alluvial deposits cover the east. They contain shale, clay, sandy clay, gravels, pebbles and fine to coarse sand. 
RASĀYAN J. Chem.

Vol. 11 | No. 2 |620 - 633 | April - June | 2018

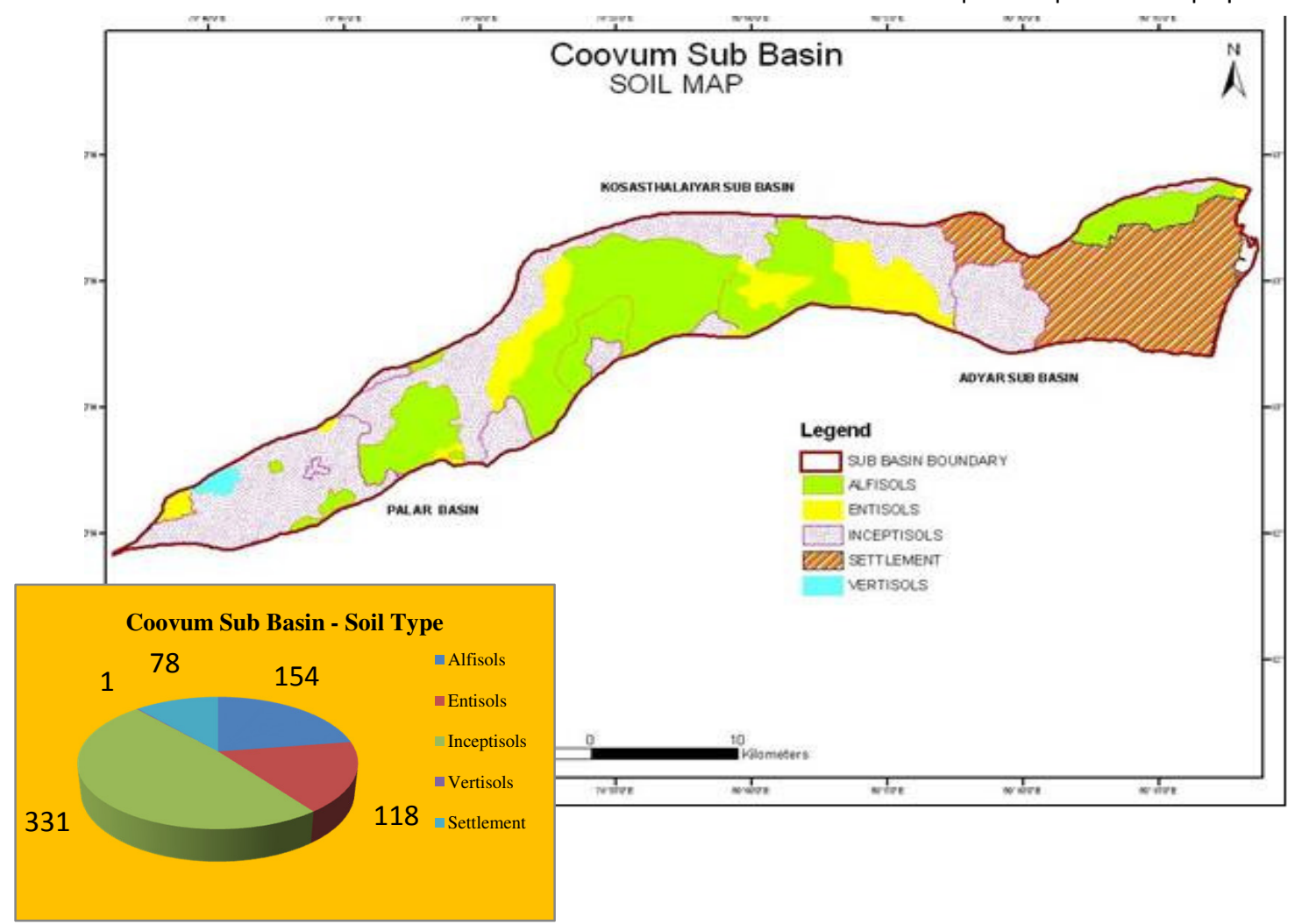

Fig.-4: Soil Map

Table 2. Soil type in Cooum Basin, Chennai

\begin{tabular}{c|c|c}
\hline Order & Area $-\mathrm{km}^{2}$ & Percentage (\%) \\
\hline Alfisols & 154 & 23 \\
\hline Entisols & 118 & 17 \\
\hline Inceptisols & 331 & 49 \\
\hline Vertisols & 1 & 0 \\
\hline Settlement & 78 & 11 \\
\hline Total & 682 & 100 \\
\hline
\end{tabular}

\section{Hydro Geology}

Ground water occurs under confined and unconfined conditions. Yield in boreholes varies from 45 to 454 lpm.

\section{Geomorphology}

Chennai area mainly consists crystalline rocks, which spread out right to the coast to the South Chennai. Mostly this area topography shows wide topographic high in the central part of Chennai sector. Alluvial, coastal plains, flood plain and sedimentary high ground landforms are noticed in the study area are shown in Table-3. This area occupies various geomorphologic features in the study area is shown in Fig.-5.

\section{Alluvial Plain}

Alluvial Plain is a gentle form of slope or this type will be slightly undulating land surface and almost which results in the deposition of alluvial materials by running water and they are related with main rivers and streams that were recognized by sparse surface drainage. This type occupies the second main component of the sub basin. The alluvium plain which consists of silt, clay, sand, gravel as well as organic matter. The thickness of alluvium ranges from area to area and the highest of $28 \mathrm{~m}$. The alluvial plain covered about $150 \mathrm{sq} \mathrm{km}(22 \%)$. 


\section{Coastal Plain}

Chennai is the flat coastal plain and which is known as eastern coastal plains. This type of plains and seas are mostly rich in taxonomy. The coastal plains occupy an area of $95 \mathrm{sq} \mathrm{km}(14 \%)$ of the total area.

\section{Flood Plains}

This type is an area which occupies the land adjacent to the river/stream stretches from the bank. The flow of water may join nor other drainage channels to develop separate channel or incase this flow of water does not develop the channel fully and it drops and dumps full of sediment and these occupy of about $68 \mathrm{sq} \mathrm{km}(10 \%)$.

\section{Sedimentary High Ground}

In the study the main substance is sediment formation of about $54 \%$ from the total area was occupied and the area occupied Tertiary age, consisting of laterite, sandstone, clay, silt, sand, etc. The left over $46 \%$ of the area is occupied by soil type like river alluvium, coastal alluvium and flood plain.

\section{Hydrometeorology \\ Rainfall}

The rainfall data for 34 years from 1971 were analysed for 7 stations in Cooum sub basin. The 50\% and $75 \%$ dependable rainfall are given below. (Table-4.1 and 4.2). The annual and monthly variations of rainfall for Kesavaram, Korattur and Nungampakkam are given in chart (Fig.-6).

\section{Climatological Features}

Maximum monthly average temperature-33.4 deg C (May)

Minimum monthly average temperature-24.4 deg C (December)

Maximum wind velocity ( $\mathrm{km} / \mathrm{Hr})-9.1$ (June)

Minimum wind velocity (km/Hr)-3.7 (October)

Maximum average sunshine (Hrs/day) -10.0 (April)

Table -3: Geomorphology Characters in Cooum Basin, Chennai

\begin{tabular}{c|c|c}
\hline Type & Area-km ${ }^{2}$ & $\%$ \\
\hline Alluvial plain & 150 & $22 \%$ \\
\hline Coastal plain & 95 & $14 \%$ \\
\hline Flood plain & 68 & $10 \%$ \\
\hline Sedimentary High ground & 368 & $54 \%$ \\
\hline Total & 682 & $100 \%$ \\
\hline
\end{tabular}

\section{Astronomical Tidal Analysis}

Based on the data provided by the Chennai Port Trust analysis were made on 100 years tidal levels at Chennai and the mean tidal levels have been calculated and shown in Table-4.3. The water level at Napier bridge, Periyar bridge and Quid-e-millath bridge were observed during 27 may 2007 to 2 June 2007.

\section{Surface Water Hydrology}

The Cooum sub basin has linkage with Kosasthaliar sub basin and Adyar sub basin because of Chembarampakkam tank and Chennai City water supply schemes. In olden days Chembarampakkam tank was an important tank for Agriculture activities serving an ayacut of $5429 \mathrm{Ha}$.

To feed water to this tank an anicut was constructed across Kallar the tributary of Kosaathaliyar river in 1879 and water was diverted to Cooum river through old Bangaru channel and then below this Korattur Anicut was constructed further downstream of Cooum to divert water to Chembarampakkam tank through New Bangaru channel(Table-5.1). 
RASĀYAN J. Chem.

Vol. 11 | No. 2 |620-633 | April - June | 2018

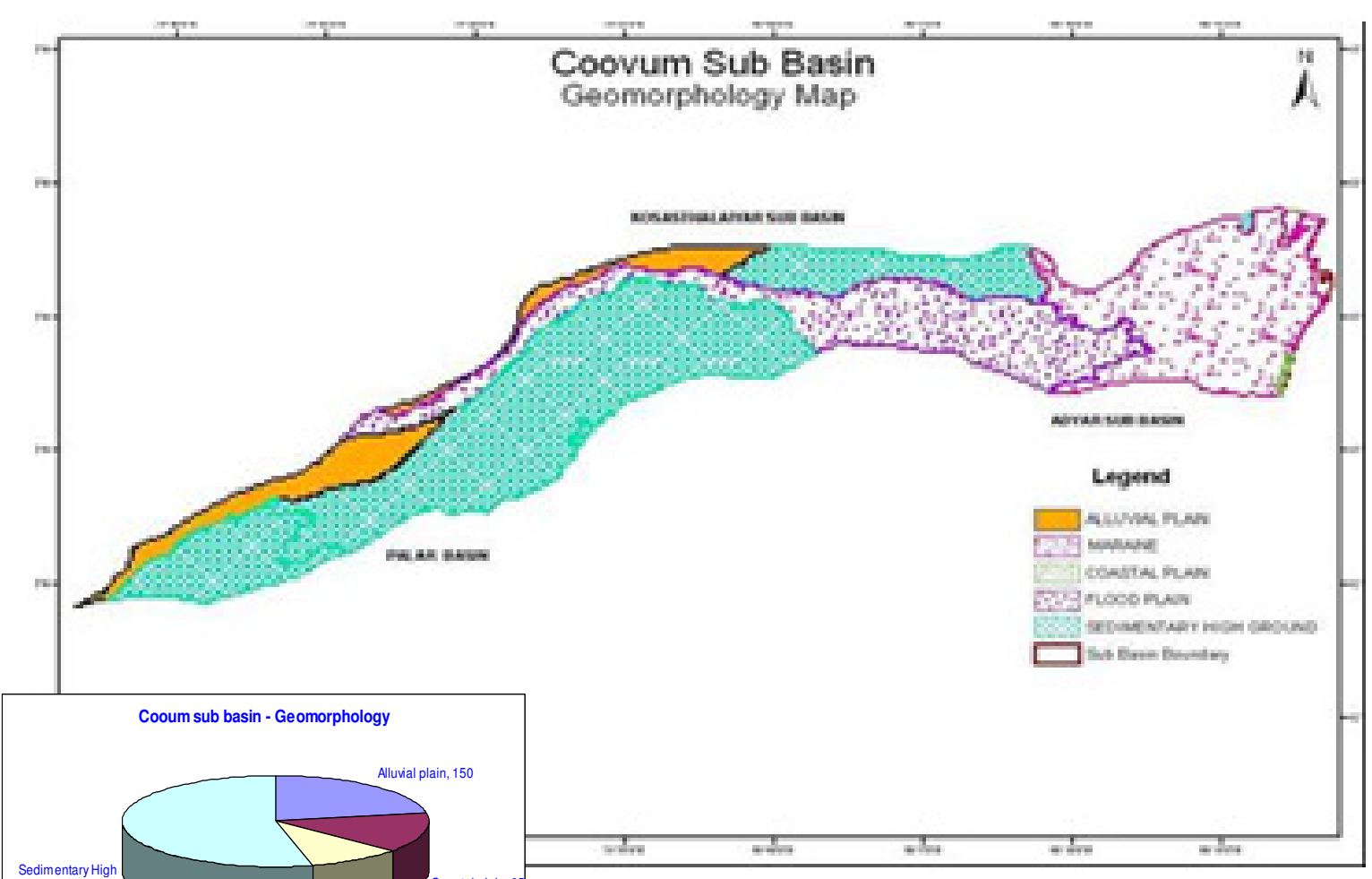

Fig.-5: Geomorphology Map

$\square$ Alluvial plain $\square$ Coastal plain $\square$ Flood plain $\square$ Sedimentary High ground

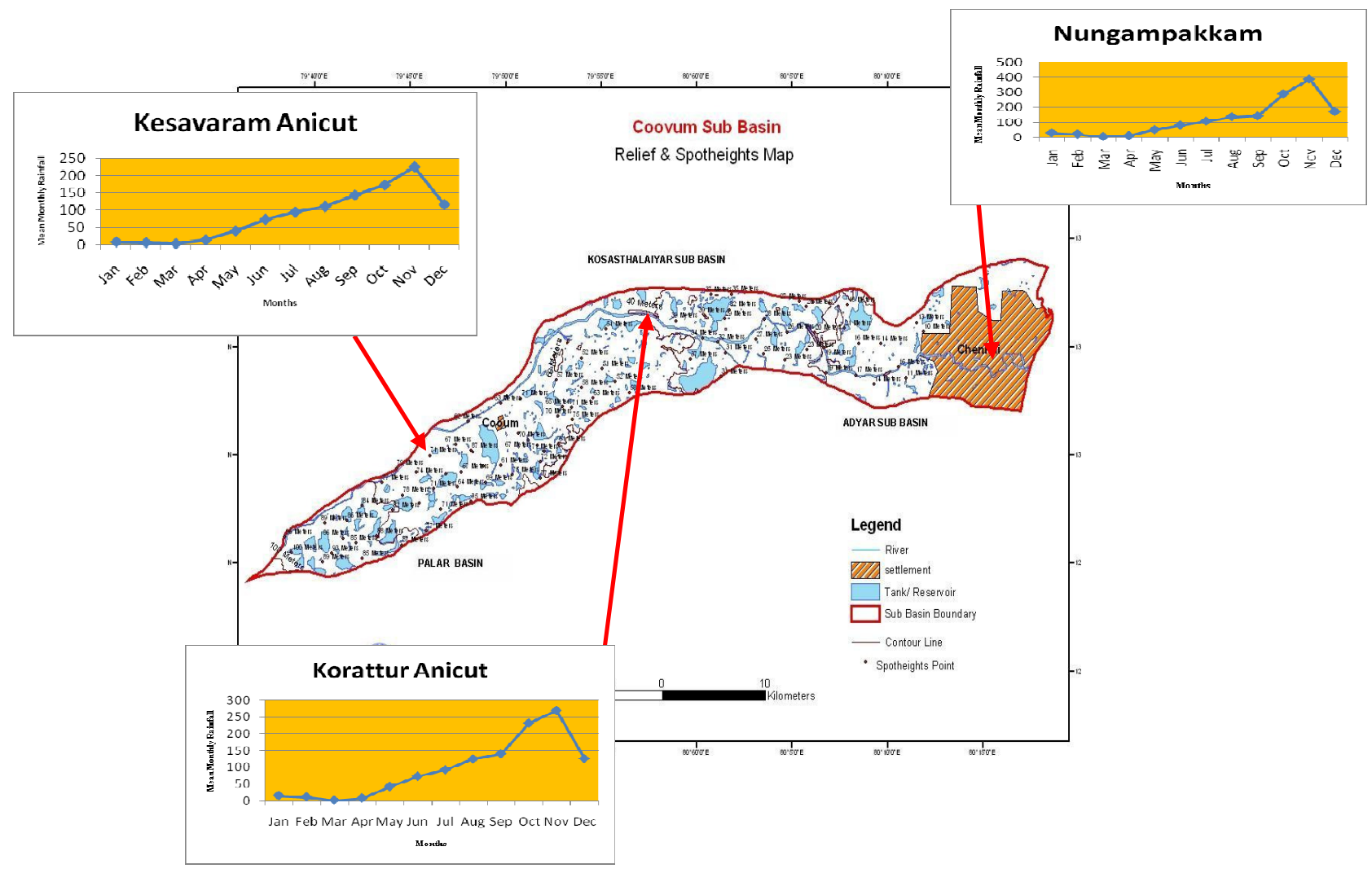

Fig.-6: Rainfall Variation 
RASĀYAN J. Chem.

Vol. 11 | No. 2 |620 - 633 | April - June | 2018

Table-4.1: Rainfall for $75 \%$ dependability in $\mathrm{mm}$

\begin{tabular}{|c|c|c|c|c|c|c|c|c|c|c|c|c|c|}
\hline Station & ฮี & ê & $\sum^{ \pm}$ & 荎 & 至 & $\Xi$ & $\Xi$ & $\stackrel{\infty}{\underset{Z}{Z}}$ & बे & $\bar{\circlearrowright}$ & zे & ف̊ & 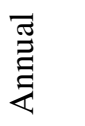 \\
\hline Kesavaram Anicut & 9 & 7 & 4 & 15 & 41 & 74 & 95 & 111 & 144 & 173 & 226 & 117 & 1015 \\
\hline Thiruvallur & 13 & 14 & 3 & 16 & 46 & 80 & 116 & 130 & 155 & 216 & 277 & 118 & 1184 \\
\hline Korattur Anicut & 16 & 12 & 2 & 8 & 43 & 73 & 93 & 125 & 141 & 232 & 270 & 126 & 1141 \\
\hline Poonamalli & 16 & 14 & 1 & 10 & 41 & 68 & 122 & 145 & 144 & 281 & 369 & 149 & 1363 \\
\hline Chembarampakkam & 29 & 25 & 3 & 18 & 54 & 93 & 129 & 168 & 163 & 291 & 409 & 168 & 1550 \\
\hline Nungampakkam & 28 & 20 & 3 & 9 & 49 & 80 & 106 & 136 & 141 & 288 & 386 & 170 & 1416 \\
\hline Chepakkam & 25 & 17 & 4 & 7 & 44 & 71 & 100 & 127 & 126 & 262 & 339 & 163 & 1283 \\
\hline
\end{tabular}

Source: IMD, Chennai

Table-4.2: Rainfall for $50 \%$ dependability in $\mathrm{mm}$

\begin{tabular}{|c|c|c|c|c|c|c|c|c|c|c|c|c|c|}
\hline 䓌 & $\Xi$ & ब0 & $\sum_{\Sigma}^{\bar{\Xi}}$ & 完 & $\stackrel{\vec{\Sigma}}{\Sigma}$ & $\Xi$ & $\Xi$ & $\stackrel{\infty 00}{\gtrless}$ & थे & $\overrightarrow{0}$ & ż & Ü & $\begin{array}{l}\stackrel{\widetilde{J}}{\Xi} \\
\text { 娄 }\end{array}$ \\
\hline Kesavaram Anicut & 7 & 6 & 3 & 11 & 31 & 57 & 73 & 85 & 110 & 132 & 173 & 89 & 777 \\
\hline Thiruvallur & 10 & 11 & 3 & 13 & 38 & 66 & 95 & 107 & 127 & 177 & 227 & 97 & 971 \\
\hline Korattur Anicut & 15 & 11 & 2 & 8 & 40 & 68 & 86 & 116 & 131 & 215 & 251 & 117 & 1060 \\
\hline Poonamalli & 14 & 12 & 1 & 9 & 36 & 59 & 106 & 125 & 125 & 243 & 319 & 128 & 1176 \\
\hline Chembarampakkam & 24 & 21 & 2 & 14 & 44 & 76 & 104 & 136 & 133 & 236 & 332 & 137 & 1259 \\
\hline Nungampakkam & 22 & 15 & 3 & 7 & 37 & 61 & 81 & 104 & 108 & 220 & 295 & 130 & 1082 \\
\hline Chepakkam & 20 & 14 & 3 & 6 & 37 & 59 & 83 & 104 & 104 & 216 & 279 & 134 & 1058 \\
\hline
\end{tabular}

Source: IMD, Chennai

Table-4.3: Mean Tidal Range at Chennai

\begin{tabular}{c|c}
\hline Description & Water level (m Asol) \\
\hline Mean Highest High Water & 0.55 \\
\hline Mean Lowest Low Water & -0.23 \\
\hline Mean Highest Water Spring & 0.77 \\
\hline Mean Highest Water Neap & 0.41 \\
\hline Mean Lowest Water Spring & -0.35 \\
\hline Mean Lowest Water Neap & -0.06 \\
\hline
\end{tabular}

Minimum average sunshine (Hrs/day)

Maximum ETo mm/month

Minimum ETo mm/month

Average ETo mm/month

Maximum monthly evaporation $\mathrm{mm}$

Minimum monthly evaporation $\mathrm{mm}$

Average annual evaporation $\mathrm{mm}$
-5.7 (July)

-251.1 (May)

-117.0 (November)

$-175.7$

-277.8 (May)

-105.2 (December)

$-2161$

Poondi reservoir was constructed across Kosasthaliyar river for Chennai City water supply. Additionally, Cholavaram and Red hills tanks were also connected with Poondi reservoir to store water for Chennai. Now Chembarampakkam and Porur tanks of Adayar sub-basin are also used for Chennai city water supply. The other important canals are Buckingham canal, Otteri Nalla, Captain cotton canal and Arumpakkam odai. Integrating groundwater and surface water management could enable the more sustainable use of both pursues a holistic approach to these various types of water resources ${ }^{3}$. 
RASĀYAN J. Chem.

Vol. 11 | No. 2 |620 - 633 | April - June | 2018

Table 5. 1 Chennai City water supply Reservoirs

\begin{tabular}{l|l|l|l|c|c}
\hline Name of Reservoirs & $\begin{array}{c}\text { Gross } \\
\text { Capacity } \\
(\mathrm{Mcm})\end{array}$ & $\begin{array}{c}\text { Live } \\
\text { Capacity } \\
(\mathrm{Mcm})\end{array}$ & $\begin{array}{c}\text { Dead } \\
\text { Storage } \\
(\mathrm{Mcm})\end{array}$ & $\begin{array}{c}\text { Catchment } \\
\text { Area } \\
(\text { Sq.km })\end{array}$ & $\begin{array}{c}\text { Water spread } \\
\text { Area (Ha) }\end{array}$ \\
\hline Chembaram pakkam & 88.30 & 87.80 & 0.50 & 77.00 & 350 \\
\hline Porur & 1.04 & 1.00 & 0.04 & 22.44 & 320 \\
\hline Poondi & 77.90 & 77.40 & 0.50 & 2704.00 & 3230 \\
\hline Red Hills & 80.75 & 80.25 & 0.50 & 59.57 & 2087 \\
\hline Cholavaram & 25.63 & 25.43 & 0.20 & 28.33 & 2258 \\
\hline
\end{tabular}

Source: Central Ground Water Board (CGWB)

\section{The Existing Hydraulic Structures}

\section{Anicuts}

As above the important anicuts in Cooum sub-basin are Kesavaram anicut and Korattur anicut. The hydraulic particulars of these anicuts are given in table 5.1 and 5.2.The other anicuts are below

1. Aranvoil anicut.

2. Ayalachery anicut

3. Paruthipattu anicut

4. Ayanampakkam anicut.

\section{City Water Supply Reservoirs}

The details of storage reservoirs for Chennai are given below:

\section{Irrigation Tanks}

In the upper and middle reach of this sub basin Agriculture is the main activity. Irrigation provides crucial water for agricultural production ${ }^{4}$. Tanks are the only source for surface water irrigation. The details of tanks are given in Table-5.2.

\begin{tabular}{|c|c|c|c|}
\hline Location & No of Tanks & $\begin{array}{c}\text { Capacity } \\
(\mathrm{Mcm})\end{array}$ & $\begin{array}{c}\text { Ayacut } \\
(\mathrm{Ha})\end{array}$ \\
\hline \multicolumn{4}{|c|}{ System Tanks } \\
\hline Above Cooum & 26 & 11.40 & 5314 \\
\hline \multicolumn{4}{|c|}{ Non System Tanks } \\
\hline Above Cooum & 15 & 4.17 & 1803 \\
\hline Above Aranvoil & 26 & 17.15 & 3784 \\
\hline Below Aranvoil & 10 & 4.93 & 2167 \\
\hline Total & 51 & 26.25 & 7754 \\
\hline \multicolumn{4}{|c|}{ Panchayat Union Tanks } \\
\hline Above Cooum & 4 & 0.50 & 97 \\
\hline Above Aranvoil & 20 & 2.50 & 533 \\
\hline Total & 24 & 3.00 & 630 \\
\hline \multicolumn{4}{|c|}{ Total Tanks } \\
\hline In sub basin & 101 & 40.65 & 13698 \\
\hline
\end{tabular}

Source: Central Ground Water Board (CGWB)

\section{Surface Water Potential}

\section{Institute for Water Studies Report}

In this sub basin the contribution of runoff is mainly during the north east monsoon period and it is less during south-west monsoon period.

The surface water potential was worked out for the $75 \%$ dependable rainfall and $50 \%$ dependable rainfall for the Southwest monsoon, Northeast monsoon and annual by runoff coefficient method. The run off coefficient adopted is 0.15 . The monthly rainfall of Thiruvallur, Korattur, Nungampakkam and 
Chepaukkam had been taken for a period of 19 years from 1974 to 1993 . The surface yield is furnished below in Table-5.3.

Table-5.3: Surface water Potential in Mcm by Run off Coefficient method.

\begin{tabular}{l|l|l|l}
\hline & South west & North east & Annual \\
\hline $50 \%$ dependability & 45.56 & 78.31 & 127.32 \\
\hline $75 \%$ dependability & 38.46 & 51.63 & 105.38 \\
\hline
\end{tabular}

Source: Chennai River Basin Report

\section{Ground Water Hydrology}

Annual Groundwater Potential

The annual average groundwater potential has been assessed blockwise by the State Ground and Surface water Resource Data Centre using Groundwater Estimation Committee norms. From this assessment, the annual average Ground water potential for Cooum sub-basin has been worked out furnished under Table6.1 .

Table-6.1: The annual average Groundwater Potential in Mcm

\begin{tabular}{l|c|c|c|c|c}
\hline \multicolumn{1}{c|}{ Block } & $\begin{array}{c}\text { Area } \\
\text { Sq.km }\end{array}$ & $\begin{array}{c}\text { Area in } \\
\text { Sub basin } \\
\text { Sq.km }\end{array}$ & $\begin{array}{c}\% \text { in } \\
\text { Sub basin }\end{array}$ & $\begin{array}{c}\text { Total } \\
\text { Potential } \\
\text { Mcm }\end{array}$ & $\begin{array}{c}\text { Potential in } \\
\text { Sub basin } \\
\text { Mcm }\end{array}$ \\
\hline Walajabad & 356 & 101 & $28 \%$ & 117.07 & 33.21 \\
\hline Sriperumbudur & 372 & 58 & $16 \%$ & 120.62 & 18.81 \\
\hline Kadambathur & 266 & 181 & $68 \%$ & 88.03 & 59.90 \\
\hline Thiruvallur & 195 & 62 & $32 \%$ & 70.14 & 22.30 \\
\hline Poondamalli & 178 & 109 & $61 \%$ & 64.80 & 39.68 \\
\hline Villivakkam & 211 & 75 & $36 \%$ & 54.59 & 19.40 \\
\hline Puzhal & 127 & 18 & $14 \%$ & 31.39 & 4.45 \\
\hline Chennai & & 78 & & & 78.00 \\
\hline Total & & 682 & & & 275.75 \\
\hline
\end{tabular}

Source: State Ground and Surface water Resource Data Centre

\section{Well Census}

As per the good census by the State Ground and Surface water Resource Data Centre, the following category wells are in the Cooum sub basin. Irrigation wells are 9349 and non irrigation wells are 78094 is shown in Table-6.2 and 6.3.

Table-6.2: Irrigation wells

\begin{tabular}{l|c|c|c|c|c|c|c}
\hline \multicolumn{1}{c|}{ Taluk } & $\begin{array}{c}\text { Open } \\
\text { wells }\end{array}$ & $\begin{array}{c}\text { Bore } \\
\text { wells }\end{array}$ & $\begin{array}{c}\text { Dug cum } \\
\text { Bore } \\
\text { wells }\end{array}$ & $\begin{array}{c}\text { Tube } \\
\text { wells }\end{array}$ & $\begin{array}{c}\text { FP } \\
\text { wells }\end{array}$ & Total & $\begin{array}{c}\text { Ayacut } \\
\text { (ha) }\end{array}$ \\
\hline Arakonam & 682 & 791 & 293 & 2 & 0 & 1770 & 1905 \\
\hline Kancheepuam & 751 & 568 & 288 & 174 & 1 & 1782 & 1421 \\
\hline Sriperumbudur & 300 & 123 & 33 & 184 & 0 & 640 & 645 \\
\hline Thiruvallur & 1110 & 1143 & 530 & 574 & 100 & 3457 & 4395 \\
\hline Poondamalli & 514 & 558 & 1 & 87 & 1 & 1161 & 909 \\
\hline Ambathur & 93 & 40 & 0 & 23 & 0 & 156 & 74 \\
\hline Total & 3452 & 3223 & 1145 & 1044 & 102 & 8966 & 9349 \\
\hline
\end{tabular}

Source: State Ground and Surface water Resource Data Centre

Table- 6.3: Non-irrigation Wells

\begin{tabular}{l|c|c|c|c}
\hline \multicolumn{1}{c|}{ Taluk } & Domestic & Industrial & Commercial & Total \\
\hline Arakonam & 195 & 7 & 4 & 206 \\
\hline Kancheepuam & 122 & 1 & 3 & 126 \\
\hline Sriperumbudur & 195 & 1 & 1 & 197 \\
\hline Thiruvallur & 3689 & 55 & 48 & 3892 \\
\hline
\end{tabular}


RASĀYAN J. Chem.

Vol. 11 | No. 2 |620 - 633 | April - June | 2018

\begin{tabular}{l|c|c|c|c}
\hline Poonamalli & 2550 & 92 & 31 & 2673 \\
\hline Ambathur & 70786 & 129 & 85 & 71000 \\
\hline Total & 77637 & 285 & 172 & 78094 \\
\hline
\end{tabular}

Source: State Ground and Surface water Resource Data Centre

\section{Ground water level variations}

The water level fluctuations have been observed during the period of five years from 2002 to 2006 . The ground water level in Chennai City is going down in the past years is shown in Table-6.4.

\section{Ground water quality}

The State Ground water and Surface water data centre have observed water quality in the wells ${ }^{5}$. Quality of groundwater is equally important to its quantity owing to the suitability of water for various purposes $^{9}$. In the coastal area the salinity in terms of Electrical conductivity values is found to be high due to sea water intrusion. The ground water pollution has been observed in Ambatur area due to industrial effluent discharges. The ground water quality has been furnished in Tables-6.5 and 6.6.

Table-6.4: The average annual variations in $\mathrm{m}$

\begin{tabular}{c|c|c|c|c}
\hline Year & Avadi & Govindavadi & Thandalam & Purisai \\
\hline 2002 & 4.6 & 19.4 & 3.0 & 14.9 \\
\hline 2003 & 3.9 & 20.1 & 2.4 & 16.2 \\
\hline 2004 & 6.0 & 20.7 & 2.6 & 16.6 \\
\hline 2005 & 8.1 & 22.2 & 2.0 & 16.7 \\
\hline 2006 & 4.7 & 19.8 & 2.8 & 12.9 \\
\hline
\end{tabular}

Source: State Ground and Surface water Resource Data Centre

Table-6.5: Ground water quality

\begin{tabular}{l|c|c}
\hline \multicolumn{1}{c|}{ Contents } & Arumpakkam & Vepery \\
\hline Date & $16-7-2003$ & $16-7-2003$ \\
\hline $\mathrm{Ca}$ & 52 & 80 \\
\hline $\mathrm{SO} 4$ & 67 & 720 \\
\hline $\mathrm{Cl}$ & 131 & 262 \\
\hline $\mathrm{NO} 2+\mathrm{NO} 3$ & 16 & 4 \\
\hline $\mathrm{TDS}$ & 645 & 1919 \\
\hline Hardness & 255 & 1150 \\
\hline Conductivity & 1040 & 8100 \\
\hline $\mathrm{pH}$ & 8.6 & 7.8 \\
\hline
\end{tabular}

Source: State Ground and Surface water Resource Data Centre

Table-6.6: Ground water quality

\begin{tabular}{c|c|c|c|c}
\hline Contents & Govindavadi & Thandalam & Purisai & Avadi \\
\hline Date & $13-7-2006$ & $13-7-2006$ & $13-7-2006$ & $13-7-2006$ \\
\hline $\mathrm{Ca}$ & 44 & 68 & 76 & 40 \\
\hline $\mathrm{Mg}$ & 63 & 71 & 24 & 107 \\
\hline $\mathrm{Na}$ & 246 & 110 & 191 & 357 \\
\hline $\mathrm{K}$ & 9 & 3 & 65 & 5 \\
\hline $\mathrm{HCO} 3$ & 354 & 165 & 342 & 256 \\
\hline $\mathrm{CO} 3$ & 0 & 0 & 12 & 0 \\
\hline $\mathrm{SO} 4$ & 117 & 177 & 144 & 672 \\
\hline $\mathrm{Cl}$ & 347 & 347 & 191 & 284 \\
\hline
\end{tabular}


RASĀYAN J. Chem.

Vol. 11 | No. 2 |620 - 633 | April - June | 2018

\begin{tabular}{c|c|c|c|c}
\hline NO3 & 4 & 0 & 18 & 4 \\
\hline $\mathrm{F}$ & 0 & 0 & 0 & 0 \\
\hline TDS & 1021 & 859 & 954 & 1611 \\
\hline Hardness & 370 & 460 & 290 & 540 \\
\hline Conductivity & 1760 & 1880 & 1470 & 2540 \\
\hline $\mathrm{pH}$ & 7.5 & 8.0 & 8.7 & 8.6 \\
\hline
\end{tabular}

\section{Favorable Zonal Map for Surface and Groundwater}

With all the thematic layers, it has been finalized the main zones for sustainable development for surface and groundwater in Cooum Basin of Chennai Basin is shown in Fig.-7.

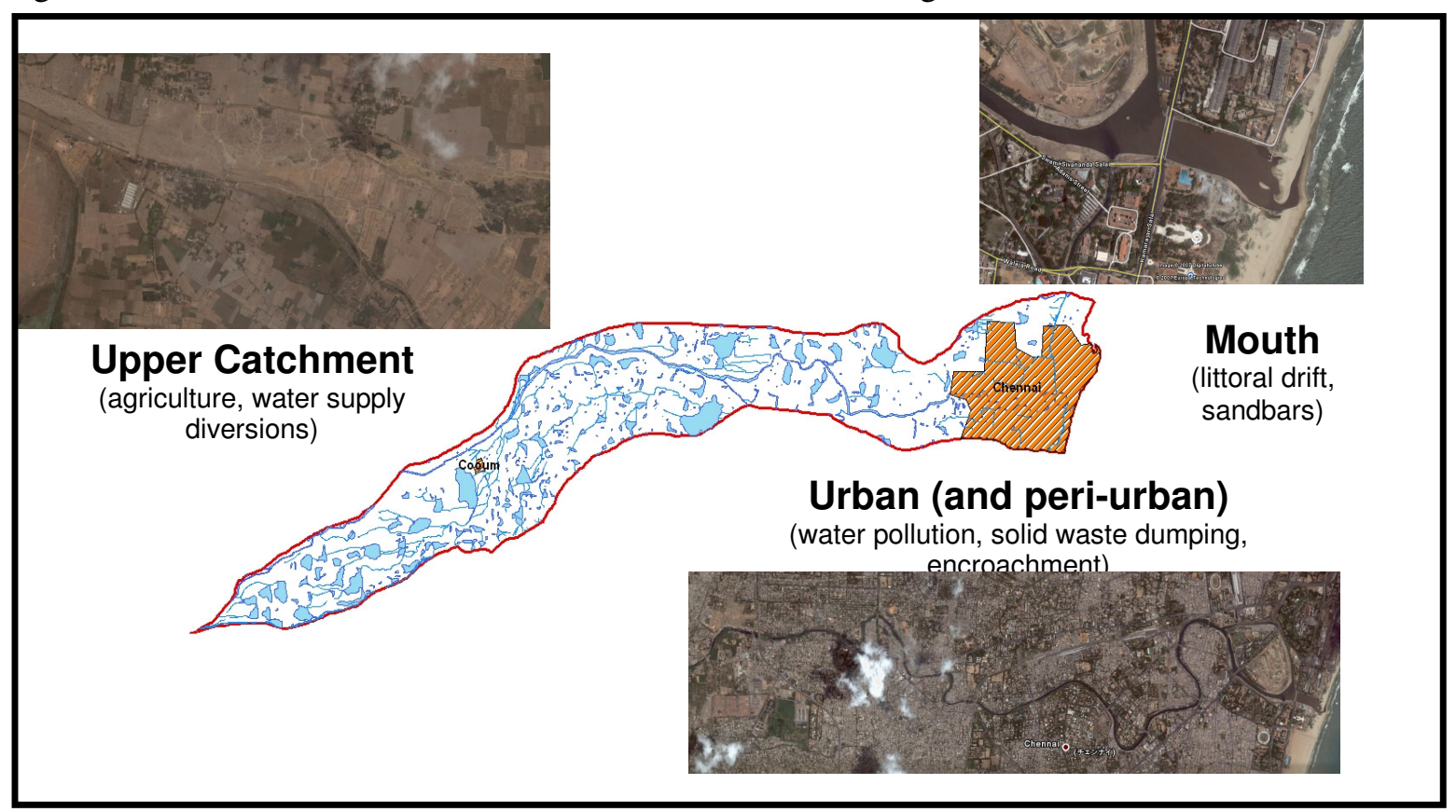

Fig.-7: Cooum Zones

\section{CONCLUSION}

The significance of integrated geospatial technology has clearly proved its usefulness in understanding the factors dependable for maintaining the hydrological cycle mainly the vegetation cover, surface water bodies, litho types and landforms. The groundwater prospects maps form a very good database and help in classifying the favorable zones (prospective zones) around the narrowing down the target areas. Recharge is the most important factor in groundwater studies. If sufficient recharge is not there, the most favorable aquifer zones will also become dry. The multi-parametric method of the technique is lucrative and this technique is better than the conventional method. This type of research is useful for analysis of influencing factors to identify the groundwater potential recharge sites.

\section{REFERENCES}

1. S. R. Daines and J.R. Pawar, Report prepared for the U.S Agency for International Development Mission to India, New Delhi, India, PN-AB6 578 (1987).

2. G. Eiden, An Integrated Compendium of Twenty One Encyclopedias In: Land-cover and Land-use mapping", Land-use, Land-cover and soil science, Encyclopedia of life support systems (EOLSS) Co.UK, pp. 1-7 (2012). 


\section{RASĀYAN J. Chem.}

Vol. 11 | No. 2 |620 - 633 | April - June | 2018

3. K. Patterson, 2009. A case for integrating Groundwater and Surface water Management, in: D. Michel and A. Pandya (Eds.), Troubled Waters: Climate Change, Hydropolitics and Transboundary Resources, E-Publishing Inc., Washington, pp. 63-72.

4. R.S. Meinzen-Dick, Research Report 105. Washington, DC: International Food Policy Research Institute, PN-ABZ-947 (1996).

5. PWD, Report of Institute of Water Studies, Tamil Nadu (2007).

6. T. Shah, Oxford University Press, (1993).

7. $\mathrm{S}$.

Suresh

2012,

Available

from, https://www.revolvy.com/main/index.php?s=Coovum\%20River\&item_type=topic \&sr=50 (2012).

8. Yasodharan Suresh and Nagamani, J. Advanced Research in Geo Sciences \& Remote Sensing, 2, 162 (2015).

9. S. D. Jadhav, R. S. Sawant, A. G. Godghate, S. R. Patil and R. S. Patil, Rasayan J. Chem., 5 (2), 246 (2012).

[RJC-1809/018] 